\title{
Response of Lymantria dispar (Lepidoptera: Lymantriidae) larvae from differently adapted populations to allelochemical stress: Effects of tannic acid
}

\author{
MariJa MRDAKOViĆ ${ }^{1}$, Vesna PERIĆ MATARUGA ${ }^{1}$, Larisa ILIJIN ${ }^{1}$, Milena VLAhOViĆ ${ }^{1}$, \\ MiLENA JANKOVIĆ TOMANIĆ ${ }^{1}$, DeJAN MIRČIĆ ${ }^{2}$ and JeLICA LAZAREVIĆ ${ }^{1}$ \\ ${ }^{1}$ Department of Insect Physiology and Biochemistry, Institute for Biological Research "Siniša Stanković", University of Belgrade, \\ Belgrade, Serbia; e-mail: mm1507@ibiss.bg.ac.rs \\ ${ }^{2}$ Department of Biomedical Science, State University of Novi Pazar, Novi Pazar, Serbia
}

Key words. Lepidoptera, Lymantriidae, Lymantria dispar, gypsy moth, tannic acid, allelochemical stress, digestive enzymes, phenotypic plasticity

\begin{abstract}
The effects of tannic acid on mean values and genetic variation in fitness-related traits (mass, relative growth rate) and specific activities of digestive enzymes (total proteases, $\alpha$-glucosidase and lipase), and genetic variation in their plasticity, were investigated in fifth instar larvae of Lymantria dispar L. (Lepidoptera: Lymantriidae) originating from two populations with different host use histories (oak and locust-tree). The two populations did not differentiate with respect to fitness-related traits, i.e. adverse effects of tannic acid were similar in both populations. However, Robinia larvae, which originated from the locust-tree forest, were characterized by higher total protease and lipase activity and lower $\alpha$-glucosidase activity than Quercus larvae, which originated from the oak forest. Higher plasticity of lipase and lower plasticity of $\alpha$-glucosidase in response to tannic acid were also recorded. Quantitative genetic analysis revealed mostly significant expression of genetic variation in the examined traits and trait plasticity, suggesting the potential for evolution of adaptive plastic responses to new environmental conditions and presence of a stressor. The genetic correlations observed between the environments significantly differed from "one", which indicates there are no constraints on the evolution of trait plasticity.
\end{abstract}

\section{INTRODUCTION}

Plants synthesize numerous allelochemicals for defence against herbivorous insects, which, on the other hand, express considerable phenotypic plasticity in preference and performance that enable them to overcome the harmful effects of the allelochemicals. Phenotypic plasticity, the property of a given genotype to produce different phenotypes in response to distinct environmental conditions, is common in insects and often highly adaptive (Pigliucci, 2001; Görür, 2005). Abundant genetic variation for a variety of plastic responses in natural populations makes possible evolution of plasticity by natural selection and other evolutionary mechanisms (Pigliucci et al., 2006). In phytophagous insects plasticity can be expressed in response to variation in the nutritive and anti-nutritive traits of their host plants (Haribal \& Renwick, 2005; Leal-Aguilar et al., 2008). Phytophagous insects have many mechanisms for overcoming the harmful effects of plant defensive compounds, among others, a powerful assemblage of digestive enzymes, antioxidative and detoxification enzymes (Broadway, 1997; Mello \& Silva-Filho, 2002; Zhu-Salzman et al., 2005; Després et al., 2007). Plasticity of digestive enzymes, i.e. changes in their synthesis and secretion and/or induction of different isoforms, may significantly affect the life history traits of individuals in changing and stressful environments. Phytophagous insects can use different host plants in different parts of their geographic distribution, but in particular environments populations usually use a small number of host plants (Ruiz-Montoya et al., 2003). Variation in the use of different host plants reveals patterns of the local adaptations of insect populations and also indicates responses to past selection (Ueno et al., 2001a).

As a phytophagous insect that feeds on over 500 plant species within 73 families (Lance, 1983; Liebhold et al., 1995) the gypsy moth must adapt to a wide-range of host plant specific defenses. Gypsy moth larvae feed on the leaves of many different species of tree that contain tanins (Barbosa \& Krischik, 1987; Liebhold et al., 1995). Tannins are the most abundant secondary metabolites found in vascular plants in both temperate and tropical areas, with a role in defence against insect herbivores by deterrence and/or toxicity. Both hydrolyzable and condensed tannins have significant effects on herbivores. In insects with a high gut $\mathrm{pH}$, tannins are prone to act as prooxidants. They produce reactive oxygen species, which can damage nutrients and/or midgut tissue and accordingly influence insect performance (Barbehenn \& Constabel, 2011 and references therein). During the course of evolution insects have acquired various mechanisms that have enabled them to tolerate ingested tannins, such as an alkaline gut $\mathrm{pH}$, low gut redox potential, surfactants, and ultrafiltration through peritrophic membranes (Berenbaum, 1980; Barbehenn \& Martin, 1994; Johnston \& Felton, 1996; Zimmer, 1997).

Gypsy moth larvae from two populations with different trophic adaptations, originating from oak (suitable host plant) and locust-tree (marginally suitable host plant) for- 
ests were studied. There are both condensed and hydrolyzable tannins in oak and locust-tree leaves (Schultz \& Baldwin, 1982; Rossiter et al., 1988; Rakesh et al., 2000), although the tannin content is higher in the latter. Unruh Snyder et al. (2007) record 10\% condensed and 18-34\% hydrolyzable tannins in locust-tree leaves, while Montgomery (1986) records lower levels of both types of tannins in leaves of several oak species. Locust-tree leaves also contain some other allelochemicals, e.g. alkaloids, flavonoids and flavonoid glycosides (Barbosa \& Krischik, 1987; Nasir et al., 2005; Veitch et al., 2010), and are characterized by a higher buffering capacity and lower nutrient content, compared to oak leaves (Montgomery, 1986 and pers. comm.; Barbosa \& Krischik, 1987). Tanniferous plants with relatively low protein levels would be more deterrent to herbivores than more nutritious plants containing the same levels of tannins (Barbehenn \& Constabel, 2011). However, the gypsy moth population from the locust-tree forest used in this study had experienced locust-tree leaves as the only food resource for more than 50 years, i.e. 50 generations (Sidor \& Jodal, 1983). Previous investigations of gypsy moth larvae from the two populations (oak and locust-tree forests) revealed local differentiation for some fitness, behavioural and physiological traits (Perić Mataruga et al., 1997; Lazarević et al., 2002, 2003).

The present work deals with the effect of tannic acid, a hydrolyzable tannin, in the rearing diet on mean values and genetic variation of mass, relative growth rate and specific activities of digestive enzymes (total proteases, $\alpha$-glucosidase and lipase) in gypsy moth larvae from the two populations. We examined the effect of allelochemical stress on genetic variation of the traits and population differences in expression of this variation due to different host use histories. Since the gypsy moth is known as a composite generalist, in which the dietbreadth of the individuals is narrower than that of the population (Rossiter, 1987), we also estimated genetic variation of phenotypic plasticity of the traits in response to dietary tannic acid (i.e. "genotype $\times$ environment" interaction) in gypsy moth larvae from different populations, and assessed possible constraints on the evolution of an optimal phenotypic plasticity.

\section{MATERIAL AND METHODS}

\section{Insect rearing}

Thirty two egg masses of gypsy moth Lymantria dispar (Linnaeus, 1758) were collected from a mixed (predominantly Quercus cerris L.) oak forest within the Bogovadja forest complex and are referred to in this study as the Quercus population, (locality "Bogovadja", $70 \mathrm{~km}$ south-west of Belgrade). Twenty six egg masses were collected from a plantation of locust-trees (Robinia pseudoacacia L.) and are referred to as the Robinia population (locality "Bagremara" near Bačka Palanka, 122 km north-west of Belgrade), as previously described in Mrdaković et al. (2011). The forest complex "Bagremara" is almost completely covered by black locust trees with a very few black walnut and English oak trees. In this forest defoliation never occurs, i.e. the population dynamics oscillates with smaller amplitude than in an oak forest (Sidor \& Jodal, 1983). The nearest oak forest, Karavukovo complex, is located $30 \mathrm{~km}$ north-west of Bačka Palanka.

The egg masses were kept in a refrigerator at $4^{\circ} \mathrm{C}$ until May, when they were transferred to a constant temperature of $23^{\circ} \mathrm{C}$ to hatch. They were reared at $23^{\circ} \mathrm{C}$ and a $12 \mathrm{~L}: 12 \mathrm{D}$ photoperiod. After moulting to the fourth instar the larvae were reared individually, in Petri dishes ( $9 \mathrm{~cm}$ diameter), and were provided daily with fresh food.

Adult gypsy moths do not feed and the females emerge with adequate energy reserves to develop and lay most of their eggs. The entire reproductive output of a female is represented in a single egg mass, which is the product of a single mating (Doane, 1968; Rossiter, 1987). Hence, all the larvae that hatch from an egg mass (family) are full-sibs. From both populations, 7-9 larvae from each egg mass (unbalanced full-sib design) were randomly assigned to the group fed on the control diet, the high wheat-germ based (HWG) standard laboratory diet of the gypsy moth (O'Dell et al., 1985), and the group fed on the HWG diet containing 5\% tannic acid (Tannic Acid, lot number 32K1248, Sigma-Aldrich). Use of the artificial diet reduced the variation in quality associated with natural diets, while the amount of tannic acid used was in the concentration range known to influence the performance of gypsy moth and other polyphagous tree-feeding Lepidoptera (Karowe, 1989; Bourchier \& Nealis, 1993). Accordingly, there were four experimental groups: Quercus larvae fed on the control diet (QC), Quercus larvae fed on the tannin supplemented diet (QT), Robinia larvae fed on the control diet (RC) and Robinia larvae fed on the tannin supplemented diet (RT).

\section{Fitness-related larval traits}

In order to estimate the effects of tannic acid on larvae from differently adapted populations, the following traits were measured for each larva: mass on the third day after moulting to the fifth instar $\left(\mathrm{LM}_{3}\right)$ and relative growth rate from $3^{\text {rd }}$ to $4^{\text {th }}$ moult (RGR). Relative growth rate was calculated as the difference between the natural logarithms of the larval mass determined after $4^{\text {th }}$ (LM5) and $3^{\text {rd }}$ moult (LM4), divided by the duration of the fourth instar (t4): (ln LM5-ln LM4) / t4 (Giertych et al., 2005). Larval mortality was very low, and hence it was omitted from the results.

\section{Preparation of midgut homogenates}

Larvae were weighed 3 days after moulting to the fifth instar. After immobilization on ice their midguts were removed, washed several times with ice-cold physiological saline, weighed and kept in a freezer at $-20^{\circ} \mathrm{C}$ until homogenization. The midguts were homogenized individually on ice in $0.15 \mathrm{M}$ $\mathrm{NaCl}$ (final tissue concentration $-100 \mathrm{mg} / \mathrm{ml}$ ) for $30 \mathrm{~s}$ and then centrifuged at $10,000 \mathrm{~g}$ for $20 \mathrm{~min}$ at $4^{\circ} \mathrm{C}$. The supernatants (crude midgut extracts) were used for determination of specific activities of total proteases (TP), $\alpha$-glucosidase $(\alpha-G)$ and lipase (Lip).

\section{Enzyme assays}

The activity of total proteases was determined using casein as the substrate, by measuring the absorbance of aromatic amino acid products of the enzyme reaction - tryptophan and tyrosine, at $280 \mathrm{~nm}$ (Kunitz, 1947). The activity of $\alpha$-glucosidase was determined using p-nitrophenyl $\alpha$-D glucopyranoside as the substrate, by measuring the absorbance of the product, p-nitrophenol, at $405 \mathrm{~nm}$ (Baker, 1991). Enzyme activities were measured in triplicate and controls without enzyme or without substrate were included. Lipase activity was determined using p-nitrophenyl caprylate as the substrate, by continuous monitoring of the release of p-nitrophenol at $410 \mathrm{~nm}$ (Mrdaković et al., 2008). Specific enzyme activities were expressed as U/mg of 


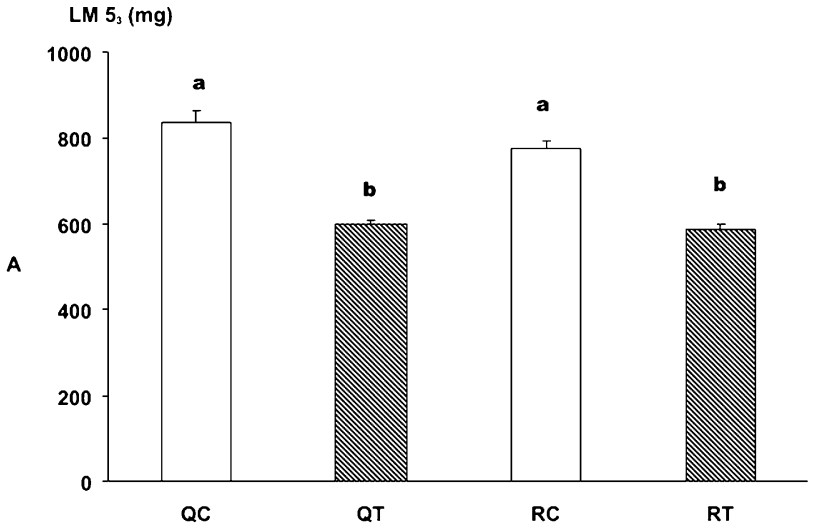

$\operatorname{RGR}(m g / d)$

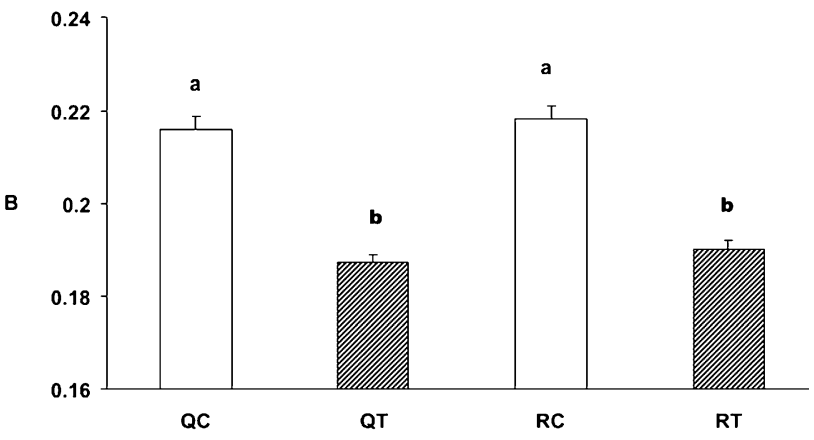

Fig. 1. Means ( \pm S.E.) for A: larval mass on the third day after moulting to the $5^{\text {th }}$ instar $\left(\mathrm{LM}_{3}\right)$ and $\mathrm{B}$ : relative growth rate from $3^{\text {rd }}$ to $4^{\text {th }}$ moult (RGR) of gypsy moth larvae from Quercus and Robinia populations reared on the control diet (QC and RC, respectively) and diet with 5\% tannic acid (QT and RT). Values marked with different letters differ significantly (Sheffe's multiple range test). Sample sizes for $\mathrm{LM}_{3}: \mathrm{N}_{\mathrm{QC}}=194, \mathrm{~N}_{\mathrm{QT}}=227$, $\mathrm{N}_{\mathrm{RC}}=172, \mathrm{~N}_{\mathrm{RT}}=191$; Sample sizes for RGR: $\mathrm{N}_{\mathrm{QC}}=175, \mathrm{~N}_{\mathrm{QT}}=$ $207, \mathrm{~N}_{\mathrm{RC}}=160, \mathrm{~N}_{\mathrm{RT}}=180$.

midgut protein, and one unit of enzyme activity is defined as the amount of enzyme that liberates $1 \mu \mathrm{mol}$ of reaction product per minute, under the given assay conditions. Protein content was determined according to Bradford (1976), using bovine serum albumin as the standard.

\section{Statistical methods}

Mean values and their standard errors were calculated for larval mass and relative growth rate, and for specific enzyme activities. The experimental groups were compared by one-way ANOVA and Sheffe's multiple range test (Sokal \& Rohlf, 1981). P-values lower than 0.05 were considered statistically significant. The analysis of variance was applied to logarithmically transformed values of the traits. Local differentiation was tested by two-way ANOVA, with population origin and tannin treatment as fixed factors. Significance of "population $\times$ treatment" interaction tests for the presence of population level specialization to tannins or, in other words, between-population genetic variation in phenotypic plasticity in response to tannins. Broad-sense heritability was calculated from one-way ANOVA, using the standard formula for an unbalanced full-sibling design: $\mathrm{H}^{2}=2 \mathrm{~V}_{\mathrm{g}} /\left(\mathrm{V}_{\mathrm{g}}+\mathrm{V}_{\text {error }}\right)$ (Becker, 1984). Comparison of trait heritabilities between the diets within each of the populations (QC-QT; RC-RT), and between two populations on each diet (QC-RC; QT-RT), were performed on z-transformed values of heritabilities. Two-way ANOVA with family and treatment as factors was carried out within both populations. Treatment

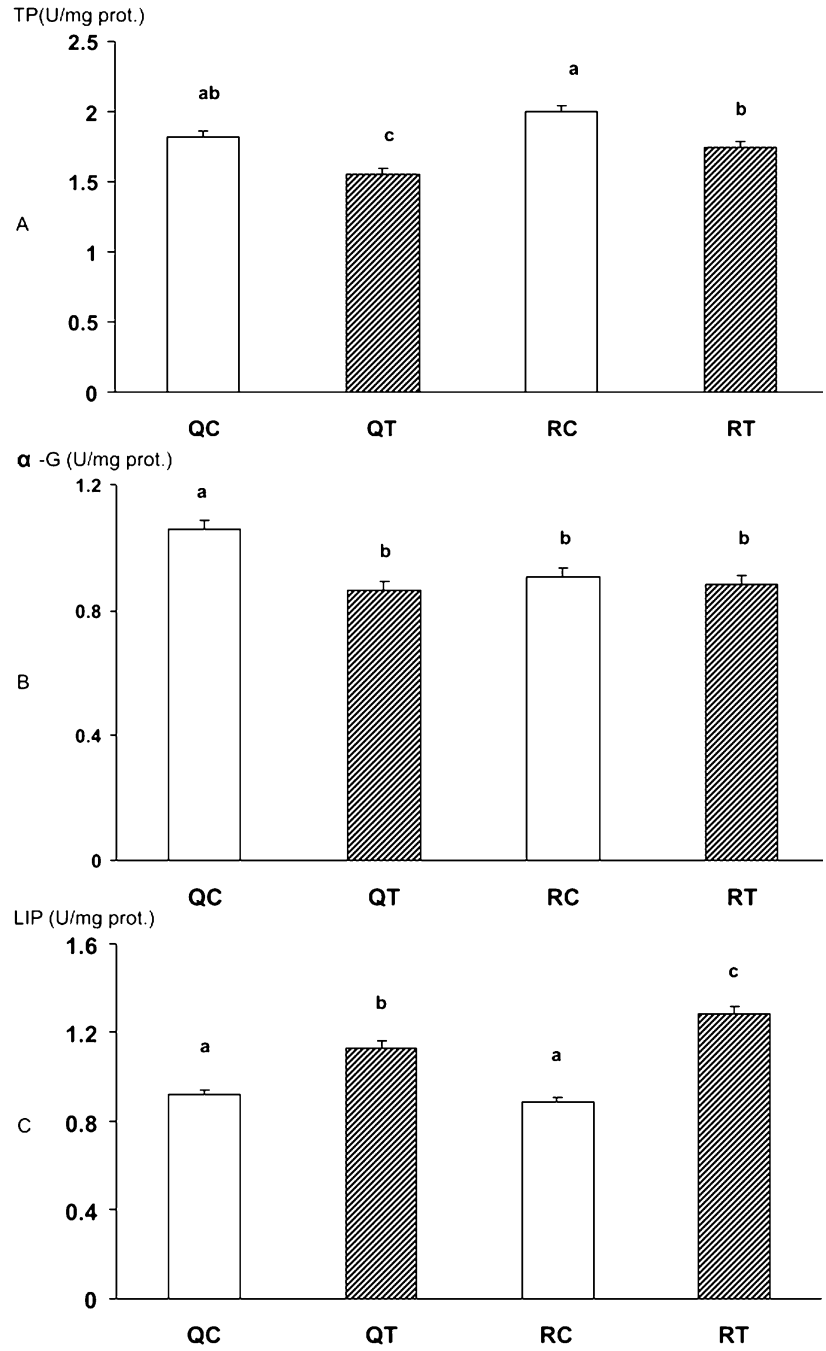

Fig. 2. Means ( \pm S.E. $)$ for specific activity of A: total proteases (TP), B: $\alpha$-glucosidase $(\alpha-G)$ and C: lipase (Lip) in $5^{\text {th }}$ instar gypsy moth from Quercus and Robinia populations reared on the control diet (QC and RC, respectively) and diet with 5\% tannic acid (QT and RT). Values marked with different letters differ significantly (Sheffe's multiple range test). Sample sizes for TP: $\mathrm{N}_{\mathrm{QC}}=215, \mathrm{~N}_{\mathrm{QT}}=238, \mathrm{~N}_{\mathrm{RC}}=176, \mathrm{~N}_{\mathrm{RT}}=193$; Sample sizes for $\alpha-\mathrm{G}: \mathrm{N}_{\mathrm{QC}}=217, \mathrm{~N}_{\mathrm{QT}}=236, \mathrm{~N}_{\mathrm{RC}}=174, \mathrm{~N}_{\mathrm{RT}}=189$; Sample sizes for Lip: $\mathrm{N}_{\mathrm{QC}}=212, \mathrm{~N}_{\mathrm{QT}}=223, \mathrm{~N}_{\mathrm{RC}}=173, \mathrm{~N}_{\mathrm{RT}}=$ 195.

was the fixed and family the random factor. A significant main effect of family indicates differences among families in trait values. A significant main effect of treatment indicates a change in the trait in response to tannic acid, i.e. phenotypic plasticity. Significant "family $\times$ treatment" interaction reveals significant variation in the level of plasticity among families, i.e. withinpopulation genetic variation for plasticity in response to dietary tannic acid. Genetic correlations across different environments (control and diet with 5\% tannic acid) were calculated as Pearson's product-moment correlations, using family means of the traits $\mathrm{r}_{\mathrm{XY}}=\operatorname{Cov}(\mathrm{X}, \mathrm{Y}) / \sqrt{ }[\operatorname{Var}(\mathrm{X}) \operatorname{Var}(\mathrm{Y})]$ (Sokal \& Rohlf, 1981; Via, 1984). All estimates came from the full-sib design and contained contributions from nonadditive genetic variance, maternal and environmental effects. 
TABLE 1. Mean squares $\left(\times 10^{3}\right)$ from two-way ANOVA for larval mass on the third day after moulting into the $5^{\text {th }}$ instar $\left(\mathrm{LM}_{3}\right)$, relative growth rate from $3^{\text {rd }}$ to $4^{\text {th }}$ moult (RGR), and specific activity of total proteases (TP), $\alpha$-glucosidase ( $\alpha$-G) and lipase (Lip) in gypsy moth larvae from the Quercus and Robinia populations, reared on the control diet and the diet with 5\% tannic acid. Population origin (Pop) and treatment (T) were fixed factors. NS-not significant.

\begin{tabular}{|c|c|c|c|c|c|}
\hline Trait & Source of variation & $\mathrm{df}$ & MS & $\mathrm{F}$ & $\mathrm{P}$ \\
\hline \multirow{4}{*}{$\mathrm{LM}_{3}$} & Pop & 1 & 0.860 & 1.865 & NS \\
\hline & $\mathrm{T}$ & 1 & 77.493 & 168.126 & $<0.001$ \\
\hline & Pop $\times T$ & 1 & 0.120 & 0.260 & NS \\
\hline & Error & 780 & 0.461 & & \\
\hline \multirow{4}{*}{ RGR } & Pop & 1 & 0.583 & 0.343 & NS \\
\hline & $\mathrm{T}$ & 1 & 191.114 & 112.309 & $<0.001$ \\
\hline & Pop $\times T$ & 1 & 0.017 & 0.007 & NS \\
\hline & Error & 717 & 1.702 & & \\
\hline \multirow{4}{*}{$\mathrm{TP}$} & Pop & 1 & 395.701 & 14.833 & $<0.001$ \\
\hline & $\mathrm{T}$ & 1 & 929.120 & 34.829 & $<0.001$ \\
\hline & Pop $\times T$ & 1 & 18.028 & 0.676 & NS \\
\hline & Error & 818 & 26.677 & & \\
\hline \multirow{4}{*}{$\alpha-G$} & Pop & 1 & 271.795 & 6.538 & $<0.05$ \\
\hline & $\mathrm{T}$ & 1 & 451.353 & 10.857 & $<0.01$ \\
\hline & Pop $\times T$ & 1 & 338.406 & 8.140 & $<0.01$ \\
\hline & Error & 812 & 41.574 & & \\
\hline \multirow{4}{*}{ LIP } & Pop & 1 & 166.877 & 6.353 & $<0.05$ \\
\hline & $\mathrm{T}$ & 1 & 3131.924 & 119.224 & $<0.001$ \\
\hline & Pop $\times T$ & 1 & 428.980 & 16.330 & $<0.001$ \\
\hline & Error & 801 & 26.269 & & \\
\hline
\end{tabular}

\section{RESULTS}

\section{Effects of tannic acid on gypsy moth larvae from two populations}

The presence of tannic acid in the diet significantly influenced larval mass (Fig. 1A) and relative growth rate (Fig. 1B). Thus, larvae from both Quercus and Robinia populations had significantly lower masses $\left(\mathrm{F}_{3,780}=\right.$ 46.654, $\mathrm{P}<0.0001)$ and significantly lower relative growth rates $\left(\mathrm{F}_{3,717}=37.783, \mathrm{P}<0.0001\right)$ when reared on the diet with $5 \%$ tannic acid than those reared on the control diet. The specific activity of total proteases (Fig. 2A) in larvae from both Quercus and Robinia populations significantly decreased in response to dietary tannic acid $\left(\mathrm{F}_{3,818}=16.679, \mathrm{P}<0.0001\right)$. The specific activity of $\alpha$-glucosidase (Fig. 2B) significantly declined in larvae from the Quercus population reared on the tannin supplemented diet $\left(\mathrm{F}_{3,812}=10.075, \mathrm{P}<0.0001\right)$. In larvae from the Robinia population, the specific activity of this enzyme was at the level recorded for Quercus larvae reared on the diet with $5 \%$ tannic acid. Unlike the activity of total proteases and $\alpha$-glucosidase, specific activity of lipase (Fig. 2C) in both Quercus and Robinia larvae was significantly higher in the presence of dietary tannic acid, than that in larvae reared on the control diet $\left(\mathrm{F}_{3,801}=\right.$ $53.722, \mathrm{P}<0.0001)$. This increase was more pronounced in larvae from the Robinia population.

\section{Differences in response of local populations to tannic acid}

Two-way ANOVA with population and tannin treatment as the factors (Table 1) revealed significant between-population differences in the activities of specific enzyme in gypsy moth larvae. On average, the specific activities of total proteases and lipase were higher in Robinia larvae, while that of $\alpha$-glucosidase was higher in

TABLE 2. Broad sense heritability $\left(\mathrm{H}^{2} \pm \mathrm{SE}\right)$ of larval mass on the third day after moulting into the $5^{\text {th }}$ instar $\left(\mathrm{LM} 5_{3}\right)$, relative growth rate from $3^{\text {rd }}$ to $4^{\text {th }}$ moult (RGR), and specific activity of total proteases (TP), $\alpha$-glucosidase ( $\left.\alpha-G\right)$ and lipase (Lip) in gypsy moth larvae from two populations. Significance of heritability was determined using t-test $(* \mathrm{P}<0.05, * * \mathrm{P}<0.01, * * * \mathrm{P}<0.001)$.

\begin{tabular}{|c|c|c|c|c|c|c|c|c|}
\hline \multirow[b]{3}{*}{$\mathrm{LM}_{3}$} & \multicolumn{4}{|c|}{ Quercus population } & \multicolumn{4}{|c|}{ Robinia population } \\
\hline & \multicolumn{2}{|c|}{$\mathrm{C}\left(\mathrm{H}^{2} \pm \mathrm{SE}\right)$} & \multicolumn{2}{|c|}{$\mathrm{T}\left(\mathrm{H}^{2} \pm \mathrm{SE}\right)$} & \multicolumn{2}{|c|}{$\mathrm{C}\left(\mathrm{H}^{2} \pm \mathrm{SE}\right)$} & \multicolumn{2}{|c|}{$\mathrm{T}\left(\mathrm{H}^{2} \pm \mathrm{SE}\right)$} \\
\hline & 0.870 & $0.168 * * *$ & 0.691 & $0.159 * * *$ & 0.061 & 0.107 & 0.504 & $0.164 * *$ \\
\hline RGR & 0.309 & 0.148 & 0.579 & $0.159 * * *$ & 0.164 & 0.133 & 0.176 & 0.124 \\
\hline $\mathrm{TP}$ & 0.203 & 0.116 & 0.205 & 0.109 & 0.306 & $0.144^{*}$ & 0.311 & $0.138^{*}$ \\
\hline$\alpha-G$ & 0.279 & $0.126^{*}$ & 0.685 & $0.155 * * *$ & 0.081 & 0.108 & 0.626 & $0.170 * *$ \\
\hline LIP & 0.397 & $0.141 * *$ & 1.024 & $0.156^{* * *}$ & 0.422 & $0.159 *$ & 0.586 & $0.166^{* *}$ \\
\hline
\end{tabular}


TABLE 3. Mean squares $\left(\times 10^{3}\right)$ from two-way ANOVA for larval mass on the third day after moulting into the $5^{\text {th }}$ instar $\left(\mathrm{LM} 5_{3}\right)$, relative growth rate from $3^{\text {rd }}$ to $4^{\text {th }}$ moult (RGR), and specific activity of total proteases (TP), $\alpha$-glucosidase ( $\alpha$-G) and lipase (Lip) in gypsy moth larvae from the Quercus population, reared on the control diet and the diet with 5\% tannic acid. Treatment (T) was fixed and family (Fam) was the random factor.

\begin{tabular}{|c|c|c|c|c|c|}
\hline Trait & Source of variation & df & MS & $\mathrm{F}$ & $\mathrm{P}$ \\
\hline \multirow{4}{*}{$\mathrm{LM}_{3}$} & Fam & 31 & 2.739 & 8.893 & $<0.001$ \\
\hline & $\mathrm{T}$ & 1 & 43.453 & 65.218 & $<0.001$ \\
\hline & Fam $\times \mathrm{T}$ & 31 & 0.666 & 2.163 & $<0.001$ \\
\hline & Error & 357 & 1.262 & & \\
\hline \multirow{4}{*}{ RGR } & Fam & 31 & 5.025 & 3.711 & $<0.001$ \\
\hline & $\mathrm{T}$ & 1 & 94.537 & 38.697 & $<0.001$ \\
\hline & Fam $\times \mathrm{T}$ & 31 & 2.443 & 1.804 & $<0.01$ \\
\hline & Error & 317 & 1.354 & & \\
\hline \multirow{4}{*}{$\mathrm{TP}$} & Fam & 31 & 49.219 & 2.055 & $<0.001$ \\
\hline & $\mathrm{T}$ & 1 & 693.562 & 19.415 & $<0.001$ \\
\hline & $\operatorname{Fam} \times \mathrm{T}$ & 31 & 35.724 & 1.492 & $<0.05$ \\
\hline & Error & 389 & 23.951 & & \\
\hline \multirow{4}{*}{$\alpha-G$} & Fam & 31 & 140.653 & 4.798 & $<0.001$ \\
\hline & $\mathrm{T}$ & 1 & 827.828 & 15.345 & $<0.001$ \\
\hline & Fam $\times \mathrm{T}$ & 31 & 53.947 & 1.840 & $<0.01$ \\
\hline & Error & 389 & 29.315 & & \\
\hline \multirow{4}{*}{ LIP } & Fam & 31 & 130.498 & 6.779 & $<0.001$ \\
\hline & $\mathrm{T}$ & 1 & 755.784 & 10.708 & $<0.01$ \\
\hline & $\operatorname{Fam} \times \mathrm{T}$ & 31 & 70.583 & 3.666 & $<0.001$ \\
\hline & Error & 371 & & & \\
\hline
\end{tabular}

larvae from the Quercus population. Significant "population $\times$ treatment" interactions, i.e. differences in response of local populations to tannin treatment, were noted for the specific activity of $\alpha$-glucosidase and lipase. Lower plasticity of $\alpha$-glucosidase and higher plasticity of lipase in response to the tannin supplemented diet were recorded for gypsy moth larvae from the Robinia population.

\section{Broad sense heritabilities}

In the Quercus population significant heritability of larval masses was recorded for larvae reared on the control and tannin supplemented diets, and for relative growth rate for those reared on the tannin supplemented diet (Table 2). In larvae from the Robinia population, heritability of larval mass increased in the presence of dietery tannic acid and became significantly higher than in those reared on the control diet (RC-RT, $\mathrm{t}=2.156, \mathrm{P}<$ 0.05 ). Heritability of larval mass was significantly higher in Quercus larvae reared on the control diet than in Robinia larvae reared on that diet $(\mathrm{QC}-\mathrm{RC}, \mathrm{t}=5.113, \mathrm{P}<$ $0.001)$.

Specific activities of total proteases in Quercus larvae, and activity of $\alpha$-glucosidase in Robinia larvae reared on the control diet, did not express significant genetic variation, while significant heritability was recorded for lipase activity in larvae from both populations (Table 2). Comparison between the diets within each population revealed significantly higher heritability for specific activity of $\alpha$-glucosidase in larvae from the Quercus (QC-QT, $\mathrm{t}=$ 2.254, $\mathrm{P}<0.05)$ and Robinia populations (RC-RT, $\mathrm{t}=$ $2.652, \mathrm{P}<0.05$ ), and for specific activity of lipase in larvae from the Quercus population (QC-QT, $\mathrm{t}=\infty, \mathrm{P}<$ 0.001 ), when they were reared on the diet with $5 \%$ tannic acid. Comparison of heritability for specific activity of lipase between larvae from the two populations reared on the tannin supplemented diet revealed significantly higher values in Quercus larvae (QT-RT, $\mathrm{t}=\infty, \mathrm{P}<0.001$ ).

\section{Genetic variation in phenotypic plasticity in response to tannic acid}

Two-way ANOVA, with family and treatment as the factors, showed significant family and treatment effects for mass and relative growth rate in Quercus (Table 3) and Robinia populations (Table 4) of gypsy moth larvae. Significant "family $\times$ treatment" interactions were recorded for mass of larvae from both populations. Concerning relative growth rate of larvae, there was a significant "family $\times$ treatment" interaction for the Quercus population, but not for the Robinia population. Significant family effects and "family $\times$ treatment" interactions were recorded for specific activities of the enzymes in both populations (Table 3 and 4). Treatment effects for specific enzyme activities were significant, except for $\alpha-G$ activity in larvae from the Robinia population (Table 4).

\section{Genetic correlations across the diets}

Estimation of genetic correlation across environments (control and 5\% tannic acid diets) within each population revealed a positive, statistically significant correlation for larval mass in the Quercus population. Concerning enzyme activities, only the specific activity of $\alpha$-gluco- 
TABLE 4. Mean squares $\left(\times 10^{3}\right)$ from two-way ANOVA for larval mass on the third day after moulting into the $5^{\text {th }}$ instar $\left(\mathrm{LM}_{3}\right)$, relative growth rate from $3^{\text {rd }}$ to $4^{\text {th }}$ moult (RGR), and specific activity of total proteases (TP), $\alpha$-glucosidase ( $\alpha$-G) and lipase (Lip) in gypsy moth larvae from the Robinia population, reared on the control diet and the diet with $5 \%$ tannic acid. Treatment (T) was fixed and family (Fam) was the random factor. NS-not significant.

\begin{tabular}{|c|c|c|c|c|c|}
\hline Trait & Source of variation & $\mathrm{df}$ & MS & $\mathrm{F}$ & $\mathrm{P}$ \\
\hline \multirow{4}{*}{$\mathrm{LM}_{3}$} & Fam & 25 & 0.641 & 1.823 & $<0.05$ \\
\hline & $\mathrm{T}$ & 1 & 29.969 & 38.885 & $<0.001$ \\
\hline & Fam $\times \mathrm{T}$ & 25 & 0.771 & 2.198 & $<0.01$ \\
\hline & Error & 311 & 1.400 & & \\
\hline \multirow{4}{*}{ RGR } & Fam & 25 & 2.530 & 1.699 & $<0.05$ \\
\hline & $\mathrm{T}$ & 1 & 81.499 & 32.939 & $<0.001$ \\
\hline & Fam $\times \mathrm{T}$ & 25 & 2.474 & 1.662 & NS \\
\hline & Error & 331 & 1.495 & & \\
\hline \multirow{4}{*}{$\mathrm{TP}$} & Fam & 25 & 62.895 & 2.758 & $<0.001$ \\
\hline & $\mathrm{T}$ & 1 & 311.151 & 8.192 & $<0.01$ \\
\hline & Fam $\times T$ & 25 & 37.982 & 1.666 & $<0.05$ \\
\hline & Error & 317 & 2.280 & & \\
\hline \multirow{4}{*}{$\alpha-G$} & Fam & 25 & 120.154 & 3.195 & $<0.001$ \\
\hline & $\mathrm{T}$ & 1 & 7.996 & 0.119 & NS \\
\hline & Fam $\times \mathrm{T}$ & 25 & 66.941 & 1.780 & $<0.05$ \\
\hline & Error & 311 & 37.601 & & \\
\hline \multirow{4}{*}{ LIP } & Fam & 25 & 36.917 & 2.405 & $<0.001$ \\
\hline & $\mathrm{T}$ & 1 & 2452.606 & 40.786 & $<0.001$ \\
\hline & Fam $\times \mathrm{T}$ & 25 & 60.134 & 3.917 & $<0.001$ \\
\hline & Error & 318 & 15.352 & & \\
\hline
\end{tabular}

sidase in the Quercus population showed a significant positive correlation across environments, which was significantly different from "one" (Table 5).

\section{DISCUSSION}

Gypsy moth larvae from both Quercus and Robinia populations showed considerable changes in the examined fitness-related traits and digestive enzyme activities in response to allelochemical stress. The presence of tannic acid in the rearing diet adversely affected larval mass and relative growth rate. Regarding the activities of digestive enzymes, phenotypic responses to dietary tannin included a decrease in total proteases activity and increase

TABLE 5. Genetic correlations across different environments (control and diet with 5\% tannic acid) for larval mass on the third day after moulting into the $5^{\text {th }}$ instar $\left(\mathrm{LM}_{3}\right)$, relative growth rate from $3^{\text {rd }}$ to $4^{\text {th }}$ moult (RGR), and specific activity of total proteases (TP), $\alpha$-glucosidase $(\alpha-G)$ and lipase (Lip) in gypsy moth larvae from two populations. The significance of correlation coefficients was determined using $\mathrm{z}$-test $(* \mathrm{P}<0.05$, $* * * \mathrm{P}<0.001)$. Significant positive correlation coefficients significantly different from "one" is marked with the letter $\mathrm{C}(\mathrm{P}<$ $0.001)$.

\begin{tabular}{ccr}
\hline & Quercus population & Robinia population \\
\hline $\mathrm{LM5}_{3}$ & $0.678^{* * *}$ & -0.220 \\
$\mathrm{RGR}$ & 0.312 & 0.010 \\
$\mathrm{TP}$ & 0.147 & 0.152 \\
$\alpha-\mathrm{G}$ & $0.436^{*} \mathrm{C}$ & 0.160 \\
$\mathrm{LIP}$ & 0.280 & -0.233 \\
\hline
\end{tabular}

in lipase activity. The specific activity of $\alpha$-glucosidase was significantly less in larvae from the Quercus population.

The ability of tannins to bind with a wide variety of compounds may lead to reduced enzyme activity and disturbed digestion with harmful effects on herbivore performance (Schoonhoven et al., 2006). However, considering protective role of gypsy moth midgut alkalinity (Berenbaum, 1980; Appel \& Maines, 1995) and tannin prooxidant activity at high gut $\mathrm{pHs}$ (Barbehenn \& Constabel, 2011), the reductions in larval mass and relative growth rate could be seen as a consequence of the higher metabolic cost of processing tannin supplemented food, and allocation of resources to energy metabolism and defense rather than growth. Also, maintaining preferred gut conditions necessary for minimizing the negative effects of dietary allelochemicals on performance might be energetically costly for gypsy moth larvae (Govenor et al., 1997). Hence, the observed changes in activities of digestive enzymes should be in accordance with the needs imposed by the presence of tannic acid in the diet and also, optimal for the given stage, fifth instar gypsy moth. The nutritional requirements of an insect alter throughout development. In older gypsy moth larvae, the change in preference from a high protein to a high lipid diet is related to increased accumulation of energy reserves required for the non-feeding stages (Stockhoff, 1993). This could be reflected through decreased total proteases activity and increased lipase activity recorded in larvae from both populations. 
Higher lipase activity may provide more energy required for induction of defense mechanisms, and is important for energy storage. Stockhoff (1993) suggests that the energy needs of the pupal and adult stages of the gypsy moth must be met by reserves accumulated during the larval stages, indicating that dietary lipids are a richer source of energy than dietary protein. Also, it is considered that surfactants are products of lipid digestion in the gut lumen (Martin \& Martin, 1984). Ingestion of tannin might cause loss of surfactant activity in $5^{\text {th }}$ gypsy moth instar (De Veau \& Schultz, 1992). Higher lipase activity leading to greater production of surfactants (phospholipids) could be an adaptive mechanism against tannins in lepidopteran larvae (Aboshi et al., 2010), i.e. the significant increase in lipase activity could reflect its participation in the process of surfactant formation.

Regarding the results for larval mass and relative growth rate it appears that tannic acid provoked adverse effects on gypsy moth larvae from both populations. Despite a long history of association with locust-tree allelochemicals, including tannins, the selection pressures were not strong enough (at least in terms of these traits) to overcome completely the negative effects of tannin in Robinia larvae. Between population differences observed through higher average activities of total proteases and lipase in larvae from the Robinia population could have resulted from past selection of many allelochemicals that favoured those larvae that could metabolize stressful food more efficiently due to increased synthesis and/or secretion of certain digestive enzymes. However, our experimental design cannot rule out the involvement of maternal effects and genetic drift in population differentiation. Significant "population $\times$ treatment" interactions are interpreted as evidence for population-level specialization to a particular food quality (Jaenike, 1981). As revealed by the significant "population $\times$ treatment" interaction, in comparison with Quercus larvae the Robinia larvae are characterized by lower plasticity of $\alpha$-glucosidase and higher plasticity of lipase in response to dietary tannic acid. The specific activity of $\alpha$-glucosidase in Robinia larvae reared on the tannin supplemented diet did not change significantly, but we cannot say if this is an adaptation due to past selection (e.g. expression of a less sensitive form of the enzyme in larvae originating from the locust-tree forest), since $\alpha$-glucosidase activity in Robinia larvae reared on the control diet was lower than in Quercus larvae also fed on the control diet. The results of an earlier study indicate a significant "population $\times$ treatment" interaction for gypsy moth pupal mass and lower susceptibility of individuals from the Robinia than from the Quercus population, to feeding on locust-tree leaves (Lazarević et al., 2002). Therefore, it is possible that the observed differences in the activity of these enzymes could affect fitness components in later developmental stages.

Previous studies reveal significantly higher longevity and pupal mass in Robinia than in Quercus gypsy moth. Significant between-population variation in phenotypic plasticity in response to feeding on locust-tree leaves is recorded for preadult viability, duration of pupal stage, as well as relative growth rate and gross growth efficiency of $4^{\text {th }}$ gypsy moth instar (Lazarevic et al., 2002, 2007). The relative growth rate of $4^{\text {th }}$ instar Robinia gypsy moth was less sensitive to locust-tree leaves than Quercus larvae. Also, Perić Mataruga et al. (2001, 2011) describe differences in number and activity of protocerebral neurosecretory neurons in gypsy moth larvae from locust-tree and oak forest populations exposed to trophic stress. Regardless of whether they are subjected to trophic stress antioxidative enzymes are more active in the midgut tissue of Robinia larvae than of Quercus larvae (Perić Mataruga et al., 1997). We did not detect an influence of dietary tannin on the duration of $4^{\text {th }}$ instar, or the duration of development from hatching to reaching the $5^{\text {th }}$ instar of Quercus and Robinia larvae (Mrdaković, 2010; Mrdaković et al., 2011). However, such a diet had similar negative effects on larval mass and relative growth rate of larvae from both populations in this study, whereas Lazarević et al. (2002) show that Robinia gypsy moth still perform better when fed on oak than locust-tree leaves. Thus, the results of this and previous investigations on oak and locust-tree populations could suggest that adaptation of gypsy moth to a marginally suitable host (locusttree) might be ongoing.

The amount of genetic variation in the fitness components expressed in novel environments is important for adaptation to those environments and broadening the ecological niche. Genetic variation can change as a direct response to the environmental conditions in which they are expressed, and several hypotheses predict increased expression of genetic variation in novel/stressful environments (Hoffman \& Merilä, 1999). Phenotypic plasticity can modulate expression of genetic variation by influencing within- and/or among-family variance of a trait. We observed that allelochemical stress provoked expression of higher genetic variation of larval mass in the Robinia population and a higher genetic variation of enzyme activities in both Quercus ( $\alpha$-glucosidase, lipase activities) and Robinia ( $\alpha$-glucosidase activity) larvae. Previous investigations have shown increased heritability of some life-history traits in gypsy moth larvae fed on locust-tree leaves and larvae exposed to greater rearing density (Lazarević, 2000; Lazarević et al., 2002).

Prolonged selection in stressful environments should remove "low" fitness alleles and decrease the heritability of a trait. Such a response was obtained for larval mass and lipase activity, which showed lower heritability in larvae from the Robinia population compared to those from the Quercus population. Similarly Ueno et al. (2001b) found lower heritability of some traits of Epilachna vigintioctomaculata on a host where the population had persisted for 50 years, compared to a population on the usual host plant.

Plasticity of traits is a mechanism that allows rapid and potentially adaptive responses of populations to environmental changes. Optimal phenotypic plasticity can evolve by selection acting on genetic variation of a trait as well as on genetic variation of trait plasticity. Heterogeneous 
environments favour increased phenotypic plasticity, although the degree of phenotypic plasticity may be reduced due to the process of canalization and tuning of development with genetic and environmental changes (Waddington, 1942). Our present results confirm that, regardless of population origin, most examined traits of the gypsy moth larvae show significant genetic variation of traits (broad sense heritability) and trait plasticities ("family $\times$ treatment" interaction) pointing to the potential for evolution of adaptive plastic responses to new environmental conditions, including the presence of an allelochemical stressor. The absence of a significant "family $\times$ treatment" effect for relative growth rate in larvae from the Robinia population suggests reduced variation in phenotypic plasticity of the trait, possibly due to the pressure of directional selection (feeding on locusttree leaves) on previous gypsy moth generations.

Across-environment genetic correlations less than "one" are a sufficient condition for selection to favour specialization on novel/stressful environments (Fry, 1996). Otherwise, evolution of optimal phenotypic plasticity would be constrained. The effects of acrossenvironment genetic correlations significantly influence the rate and direction of evolution in traits related to use of environmental resources (Via, 1984). The positive genetic correlation observed between larval masses expressed on both diets in Quercus larvae, suggests that gypsy moth families with small larval masses will also have small masses on a tannin supplemented diet. The positive genetic correlation between the specific activities of $\alpha$-glucosidase on the different diets, also observed in Quercus larvae, was significantly less than "one" and together with non-significant correlations of other traits, does not represent a constraint for the evolution of enzyme plasticity. Correlations across environments are often insignificant, but they would move toward negative values in a population adapted to multiple hosts (Joshi \& Tompson, 1995). The absence of negative correlations may mean that evolution of the norm of reaction is still in progress (Via \& Lande, 1985). However, our results came from the full-sibling analysis, and contributions from nonadditive genetic effects, maternal and environmental effects might also have affected the estimated correlations.

ACKNOWLEDGEMENT. This study was supported by the Serbian Ministry of Education and Science, grant no. 173027.

\section{REFERENCES}

Aboshi T., Yoshinaga N., Nishida R. \& Mori N. 2010: Phospholipid biosynthesis in the gut of Spodoptera litura larvae and effects of tannic acid ingestion. - Insect Biochem. Mol. Biol. 40: 325-330.

Appel H.M. \& Maines L.W. 1995: The influence of host plant on gut conditions of gypsy moth (Lymantria dispar) caterpillar. - J. Insect Physiol. 41: 241-246.

BAKER J.E. 1991: Properties of glycosidases from the maize weevil, Sitophilus zeamais. - Insect Biochem. 21: 615-621.

Barbehenn R.V. \& Constabel P.C. 2011: Tannins in plantherbivore interactions. - Phytochemistry 72: 1551-1565.
BARbehenN R.V. \& MARTIN M.M. 1994: Tannin sensitivity in Malacosoma disstria: roles of the peritrophic envelope and midgut oxidation. - J. Chem. Ecol. 20: 1985-2001.

BARBOSA P. \& KRISCHIK V.A. 1987: Influence of alkaloids on feeding preference of eastern deciduous forest trees by gypsy moth Lymantria dispar L. - Am. Nat. 130: 53-59.

BECKER W.A. 1984: Manual of Quantitative Genetics. Academic Enterprises, Pullman, WA, 188 pp.

Berendaum M. 1980: Adaptive significance of midgut $\mathrm{pH}$ in larval Lepidoptera. - Am. Nat. 115: 138-146.

BouRChIER R.S. \&. NeAlis V.G. 1993: Development and growth of early- and late-instar gypsy moth (Lepidoptera: Lymantriidae) feeding on tannin-supplemented diets. - Environ. Entomol. 22: 642-646.

BRADFORD M. 1976: A rapid and sensitive method for the quantification of microgram quantities of protein utilizing the principle of protein-dye binding. - Anal. Biochem. 72: 248-254.

BROADWAY R.M. 1997: Dietary regulation of serine proteinases that are resistant to serine proteinase inhibitors. $-J$. Insect Physiol. 43: 855-874.

Després L., David J.P. \& Gallet C. 2007: The evolutionary ecology of insect resistance to plant chemicals. - Trends Ecol. Evol. 22: 298-307.

De Veau E.J.I. \& Schultz J.C. 1992: Reassessment of interaction between gut detergents and tannins in Lepidoptera and significance for gypsy moth larvae. - J. Chem. Ecol. 18: $1437-1453$

DoANE C.C. 1968: Aspect of mating behavior of the gypsy moth. - Ann. Entomol. Soc. Am. 61: 768-773.

FRY J.D. 1996: The evolution of host specialization: Are tradeoffs overrated? - Am. Nat. 148: s84-s107.

Giertych M.J., Bakowski M., Karolewski P., ZytKowiak R. \& GrzBYta J. 2005: Influence of mineral fertilization on food quality of oak leaves and utilization efficiency of food components by the gypsy moth. - Entomol. Exp. Appl. 117: 59-69.

GöRÜR G. 2005: The importance of phenotypic plasticity in herbivorous insect. Insect speciation. In Ananthakrishnan T.N. \& Whitman D. (eds): Insect Phenotypic Plasticity, Vol. 1: Diversity of Responses. Science Publishers, Enfield, NH, pp. 145-171.

GovenoR H.L., Schultz J.C. \& Appel H.M. 1997: Impact of dietary allelochemicals on gypsy moth (Lymantria dispar) caterpillars: Importance of midgut alkalinity. - J. Insect Physiol. 43: 1169-1175.

Haribal M. \& Renwick A.A. 2005: Plasticity in insect responses to variable chemistry of host plants. In Ananthakrishnan T.N. \& Whitman D. (eds): Insect Phenotypic Plasticity, Vol. 1: Diversity of Responses. Science Publishers, Enfield, NH, pp. 59-77.

Hoffmann A.A. \& Merilä J. 1999: Heritable variation and evolution under favorable and unfavorable conditions. - Trends Ecol. Evol. 14: 96-101.

JAENIKE J. 1981: Criteria for ascertaining the existence of host races. - Am. Nat. 117: 830-834.

Johnston K.S. \& Felton G.W. 1996: Physiological and dietary influences on midgut redox conditions in generalist lepidopteran larvae. - J. Insect Physiol. 42: 191-198.

Joshi A. \& Thompson J.N. 1995: Trade-offs and the evolution of host specialization. - Evol. Ecol. 9: 82-92.

Karowe D.N. 1989: Differential effect of tannic acid on two tree-feeding Lepidoptera: implications for theories of plant anti-herbivore chemistry. - Oecologia 80: 507-512.

KunitZ M. 1947: Crystalline soybean trypsin inhibitor. II. General properties. - J. Gen. Physiol. 30: 291-310. 
LANCE D.R. 1983: Host-seeking behavior of the gypsy moth: the influence of polyphagy and highly apparent host plants. In Ahmad S. (ed.): Herbivorous Insects: Host-seeking Behavior and Mechanisms. Academic Press, New York, pp. 210-224.

Lazarević J. 2000: Physiological and Genetic Mechanisms of Adaptation to Unsuitable Nutrition in the Gypsy Moth Lymantria dispar $L$. PhD Thesis, Faculty of Biology, University of Belgrade, 166 pp. [in Serbian, English abstr.].

Lazarević J., Perić Mataruga V., Stojković B. \& Tucić N. 2002: Adaptation of the gypsy moth to an unsuitable host plant. - Entomol. Exp. Appl. 102: 75-86.

Lazarević J., Perić Mataruga V., Prolić Z. \& Tucić N. 2003: Behavioural response to an unsuitable host plant in the gypsy moth (Lymantria dispar L.). - Folia Biol. (Krakow) 51: $129-131$

Lazarević J., Perić Mataruga V. \& Tucić N. 2007: Pre-adult development and longevity in natural populations of Lymantria dispar (Lepidoptera: Lymantriidae). - Eur. J. Entomol. 104: 211-216.

Leal-Aguilar K., Ruiz-Montoya L., Perales H. \& Morales H. 2008: Phenotypic plasticity of Brevicorine brassicae in responses to nutritional quality of two related host plants. Ecol. Entomol. 33: 735-741.

Liebhold A.M., Gottschalk K.W., Muzika R.M., Montgomery M.E., Young R., O’Day K. \& Kelly B. 1995: Suitability of North American tree species to gypsy moth: a summary of field and laboratory tests. General Technical Report NE-211. USDA Forest Service, Randor, PA, 34 pp.

Martin M.M. \& Martin J.S. 1984: Surfactants: Their role in preventing the precipitation of proteins by tannins in insect guts. - Oecologia 61: 342-345.

Mello M.O. \& Silva-Filho M.C. 2002: Plant-insect interactions: an evolutionary arms race between two distinct defense mechanisms. - Braz. J. Plant Physiol. 14: 71-81.

Montgomery M.E. 1986: Gypsy moth host plant relationships and population dynamics. In Proceeding $18^{\text {th }}$ IUFRO World Congress, Division 2, Vol. II: Forest Plants and Forest Protection, Ljubljana, Slovenia, pp. 743-754.

Mrdaković M. 2010: The Evolution of Phenotypic Plasticity in Response to Nutritive Stress in the Gypsy Moth Lymantria dispar L. Larvae. PhD Thesis, Faculty of Biology, University of Belgrade, 186 pp. [in Serbian, English abstr.].

Mrdaković M., Lazarević J., Perić Mataruga V., Ilijin L. \& Vlahović M. 2008: Partial characterization of a lipase from gypsy moth (Lymantria dispar L.) larval midgut. - Folia Biol. (Krakow) 56: 103-110.

Mrdaković M., Perić Mataruga V., Ilijin L., Vlahović M., Todorović D., Nenadović V. \& Lazarević J. 2011: The effects of tannic acid on the fitness-related traits of Lymantria dispar L. larvae. - Arch. Biol. Sci. (Belgrade) 63: $1037-1045$.

Nasir H., Iqbal Z., Hiradate S. \& FujI Y. 2005: Allelopathic potential of Robinia pseudo-acacia. J. Chem. Ecol. 31: 2179-2192.

O’Dell T.M., Butt C.A. \& Bridgeforth A.W. 1985: Lymantria dispar. In Singht P. \& Moore R. (eds): Handbook of Insect Rearing. Elsevier, New York, pp. 355-367.

Perić Mataruga V., Blagojević D., Spasić M.B., Ivanović J. \& JANKOVIĆ HLADNI M. 1997: Effect of the host plant on the antioxidative defence in the midgut of Lymantria dispar L. caterpillars of different population origins. - J. Insect Physiol. $\mathbf{4 3}$ 101-106.

Perić Mataruga V., Lazarević J. \& Nenadović V. 2001: A possible role for the dorsolateral protocerebral neurosecretory neurons in the trophic adaptations of Lymantria dispar (Lepidoptera: Lymantriidae). — Eur. J. Entomol. 98: 257-264.
Perić Mataruga V., Mrdaković M., Vlahović M., Ilijin L., Janković Tomanić M., Mirčić D. \& Nenadović V. 2011: Biogenic amines in protocerebral A2 neurosecretory neurons of Lymantria dispar (Lepidoptera: Lymantriidae) - response to trophic stress. - Arch. Biol. Sci. (Belgrade) 63: 571-577.

Pigliucci M. 2001: Phenotypic Plasticity. John Hopkins University Press, Baltimore, 328 pp.

Pigliucci M., Murren C.J. \& Schlichting C.D. 2006: Phenotypic plasticity and evolution by genetic assimilation. $-J$. Exp. Biol. 209: 2362-2367.

RaKesh D.D., Bhat T.K. \& Singh B. 2000: Effect of fungal treatment on composition, tannin levels, and digestibility of black locust (Robinia pseudoacacia) leaves. - J. Gen. Appl. Microbiol. 46: 99-103.

Rossiter M.C. 1987: Genetic and phenotypic variation in diet breadth in a generalist herbivore. - Evol. Ecol. 1: 272-282.

Rossiter M.C., SchUltz J.C. \& Baldwin I.T. 1988: Relationships among defoliation, red oak phenolics, and gypsy moth growth and reproduction. - Ecology 69: 267-277.

Ruiz-Montoya I., NúÑez-Farfán J. \& VARgas J. 2003: Hostassociated genetic structure of Mexican populations of the cabbage aphid Brevicoryne brassicae L. (Homoptera: Aphididae). - Heredity 91: 415-421.

Schoonhoven L.M., van Loon J.J.A. \& Dicke M. 2006: InsectPlant Biology. Oxford University Press, Oxford, 421 pp.

Schultz J.C. \& Baldwin I.T. 1982: Oak leaf quality declines in response to defoliation by gypsy moth larvae. - Science $\mathbf{2 1 7}$ : $149-151$.

SidOR Ć. \& JODAL I.1983: Results of investigations of health conditions of gypsy moth (Porthetria dispar L.) in acacia forest "Bagremara". - Plant Prot. 34: 445-455.

SoKal R.R. \& RohlF F.J. 1981: Biometry. Freeman, San Francisco, $937 \mathrm{pp}$.

SтоскноғF B.A. 1993: Ontogenetic change in dietary selection for protein and lipid by gypsy moth larvae. - J. Insect Physiol. 39: 677-686.

Ueno H., Hasegawa Y., Funiyama N. \& Katakura H. 2001a: Population differentiation in host-plant use in a herbivorous ladybird beetle, Epilachna vigintioctomaculata. - Entomol. Exp. Appl. 99: 263-265.

Ueno H., Hasegawa Y., Fujiyama N. \& Katakura H. 2001b: Comparison of genetic variation in growth performance on normal and novel host plants in a local population of a herbivorous ladybird beetle, Epilachna vigintioctomaculata. Heredity 87: 1-7.

Unruh Snyder L.J., Luginbuhl L.-M., Mueller J.P., Conrad A.P. \& TURNER K.E. 2007: Intake, digestibility and nitrogen utilization of Robinia pseudoacacia foliage fed to growing goat wethers. - Small Rumin. Res. 71: 179-193.

VIA S. 1984: The quantitative genetics of polyphagy in an insect herbivore. II. Genetic correlations in larval performance within and among host plants. - Evolution 38: 896-905.

VIA S. \& LANDE R. 1985: Genotype-environment interaction and the evolution of phenotypic plasticity. - Evolution 39: $505-522$.

Veitch N.C., Elliott P.C., Kite G.C. \& Lewis G.P. 2010: Flavonoid glycosides of the black locust tree, Robinia pseudoacacia (Leguminosae). - Phytochemistry 71: 479-486.

WadDington C.H. 1942: Canalization of development and the inheritance of acquired characters. - Nature 150: 563-565.

Zhu-Salzman K., Bi J.-L. \& LiU T.-X. 2005: Molecular strategies of plant defense and insect counter-defense. - Insect Sci. 12: 3-15.

ZiMmER M. 1997: Surfactants in the gut fluids of Porcellio scaber (Isopoda: Oniscidae), and their interactions with phenolics. - J. Insect Physiol. 43: 1009-1014.

Received March 1, 2012; revised and accepted August 3, 2012 